\title{
Pendekatan Kolaboratif untuk Penerapan Energi Laut di Indonesia
}

\author{
Sari Noviana (1), (2), Suheri (3), Mukhtasor (2), (3)
}

(1) Universitas Teknologi Sumbawa, Sumbawa Besar

(2) Indonesian Counterpart for Energy and Environment Solutions (ICEES)

(3) Fakultas Teknologi Kelautan, Institut Teknologi Sepuluh Nopember, Surabaya

Pengembangan energi laut di Indonesia menggunakan strategi "double track", yaitu (1) mendorong pemanfaatan teknologi nasional untuk menghasilkan pembangkit listrik skala kecil demi pemerataan akses energi terutama di daerah terpencil dan perbatasan, (2) menjalin kerjasama internasional untuk implementasi energi laut skala menengah dan besar untuk mengurangi ketergantungan terhadap penggunaan bahan bakar minyak dan sumber energi konvensional lainnya (Guru besar bidang energi laut ITS, Prof. Ir. Mukhtasor, M.Eng., 2014).

Sejak tahun 2011 telah dilakukan berbagai upaya pengembangan energi laut. Mulai dari program strategis hingga pada tataran teknis. Asosiasi Energi Laut Indonesia (ASELI) yang dibentuk tahun 2011 secara massif melakukan sosialisasi, penyusunan road map regulasi, penetapan metode perhitungan potensi energi laut, survei secara berkala, hingga menjalin kerjasama nasional maupun internasional. Dan pada tataran implementasi telah dilakukan tahap field test untuk pembangkit listrik gelombang laut (PLTGL-SB 1-10 kW, 2008-2015) dan field testpembangkit listrik arus laut Tipe Darrieus (PLTAL, 2-10 kW, 2006-2015).
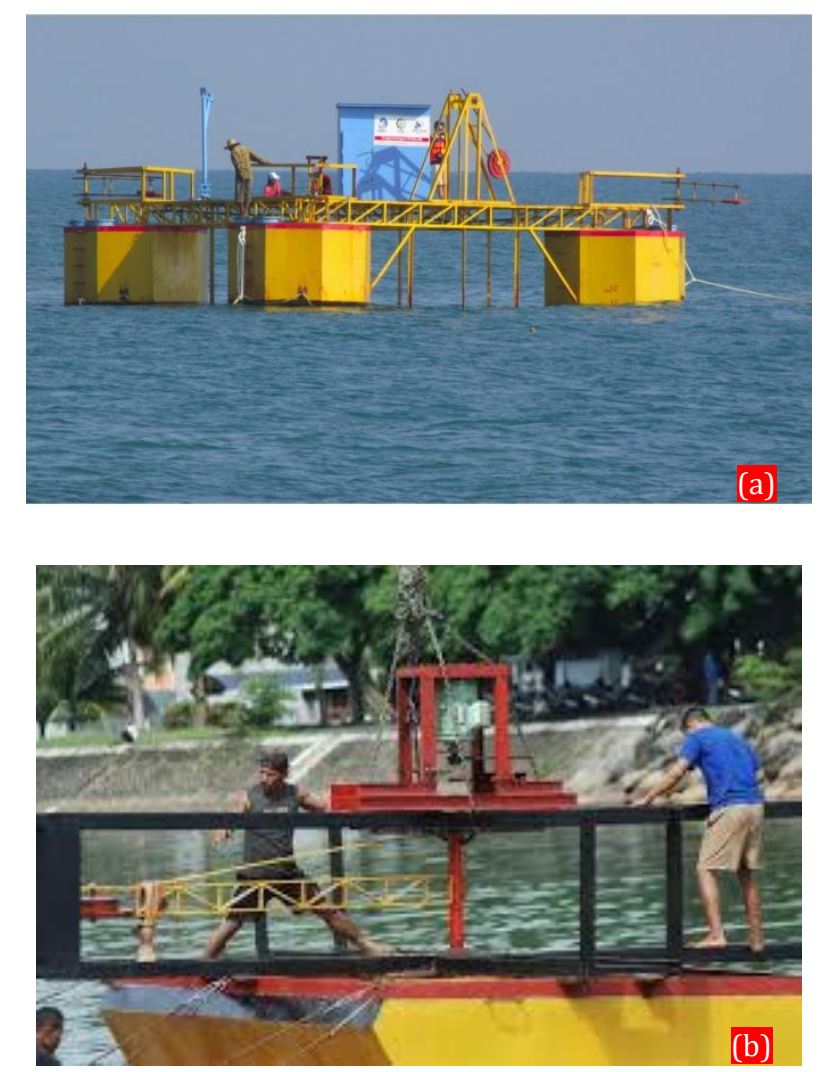

Gambar 1.

(a) Field test energi gelombang system Pendulum di Laut Larantuka(10 kW, 2013)

(b) Field testPLTGLsistem Pendulum di Padang, Sumbar(10 kW, 2011) 

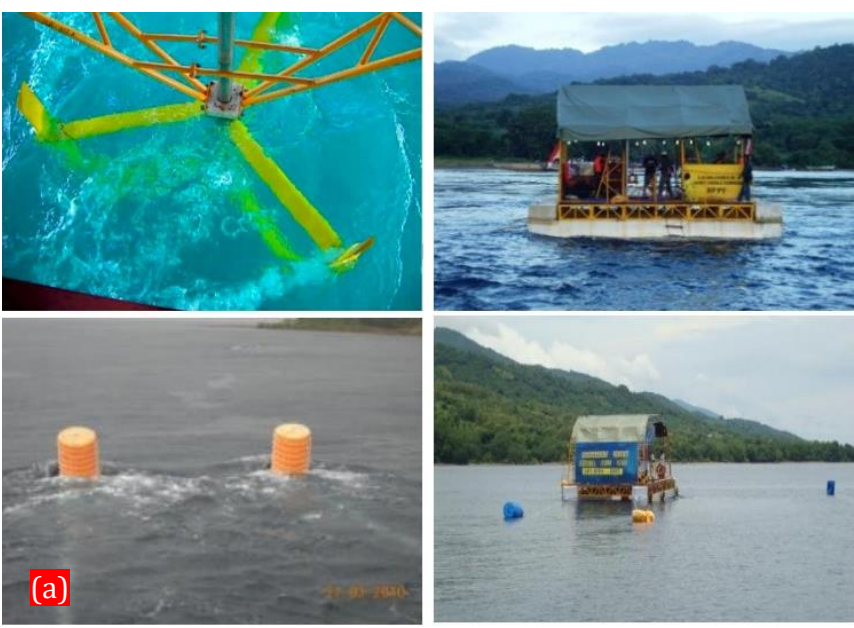
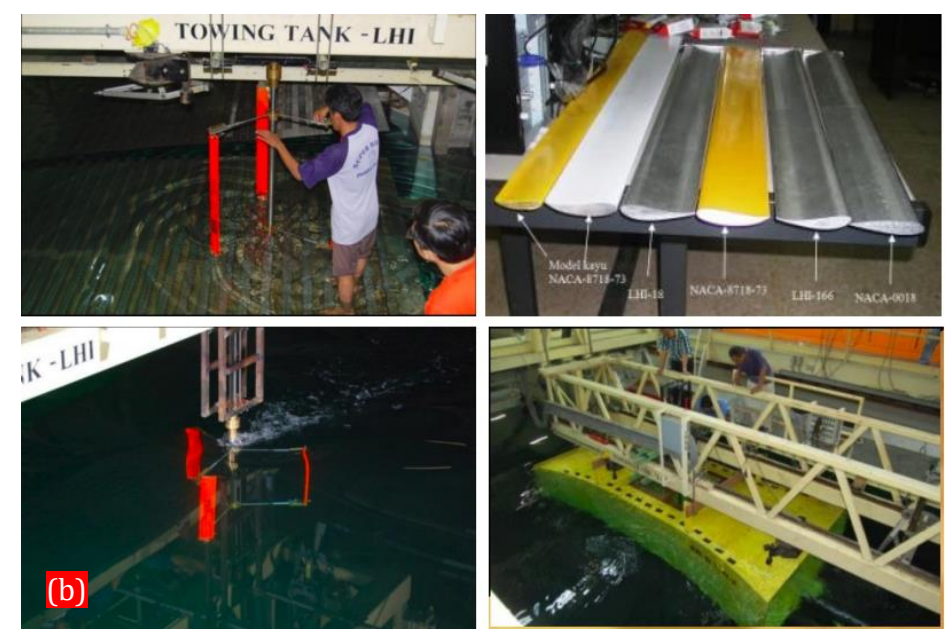

\section{Gambar 2.}

(a) Field test pembangkit listrik laboratorium PLTAL tipe Darrieus di Selat Madura (10 kW, 2006)

(b) Proses fabrikasi dan tes energi arus laut tipe Darrieus

Hingga saat ini masih dilakukan pengembangan hingga mencapai skala Industri.Dalam upaya tersebut diperlukan kolaborasi yang massif dari berbagai pihak, yaitu ilmuwan dan teknolog sebagai penyedia teknologi, pelaku bisnis investasi, pemerintah sebagai pemangku kebijakan, produsen listrik untuk produksi skala komersial, dan perangkat pendukung lainnya seperti sistem operasi dan pemeliharaan.

Terdapat 2 skema kerjasama yang diusulkan, yaitu skema kerjasama untuk skala proyek percontohan dan skema kerjasama untuk skala industri. Pada skema implementasi energi laut skala percontohan maka diperlukan kolaborasi dari universitas dalam negri yang mewakili unsur akademisi, universitas dari luar negri sebagai partner asing yang memiliki kompetensi di bidang energi laut, laboratorium balai penelitian energi laut dalam negri yang mewakili unsur tenaga ahli, pemerintahan daerah sebagai penyedia sumer daya dan sumber dana, perusahaan dalam negri sebagai pendukung pembiayaan program melalui program dana sosial, dan LSM yang bergerak di bidang energi dan lingkungan. Skema kerjasama pada skala percontohan ini juga dapat dilakukan melalui program pemerintahan pusat membentuk marine sains dan teknopark yang melibatkan pemerintah pusat sebagai pelaksana utama yang memiliki kewenangan dalam penentuan kerangka kebijakan pelaksanaan marine sains dan teknopark serta mekanisme pembiayaannya.

Program ini akan melibatkan pemerintah daerah sebagai penyedia sumber daya dan pelaksana teknis untuk operasional dan pemeliharaan jangka panjang, universitas dalam negri, universitas luar negri, laboratorium balai penelitian dalam dan luar negri, serta LSM. Untuk implementasi skala industri dilakukan melalui kolaborasi antar stakeholder yang terlibat dalam skema proyek percontohan dengan menambahkan unsur sektor swasta dalam dan luar negri yang akan berinvestasi dalam jangka panjang. Untuk mendukung kedua program tersebut, perlu dilakukan program pengembangan kapasitas SDM sebagai asset pengembang energi laut berkelanjutan. Skema kerjasama yang dilakukan adalah dengan melibatkan unsur perguruan tinggi dalam negri, perguruan tinggi asing, pemerintah pusat melalui kementrian terkait sebagai pengambil kebijakan masalah pendidikan dan pembiayaannya melalui skema beasiswa, dan pemerintah daerah sebagai unsur penyedia SDM yang akan menempuh program melalui skema delegasi/tugas belajar. Studi kasus yang akan dilakukan untuk menerapkan pola kerjasama tersebut adalah rencana pembangunan PLTAL di daerah Nusa Tenggara Barat. 
Program ini dilaksanakan mulai awal tahun 2015 dan direncanakan hingga tahun 2019. Program ini dilakukan secara integrative dan menyeluruh yangdiawali dengan skala proyek percontohan kemudian scalling up hingga skala industri. Dan program pengembangan kapasitas SDM masyarakat setempat juga dilakukan secara paralel untuk menyiapkan SDM yang akan berperan pada sistem pengoperasian dan pemeliharaan jangka panjang.

\section{Collaboration Scheme}

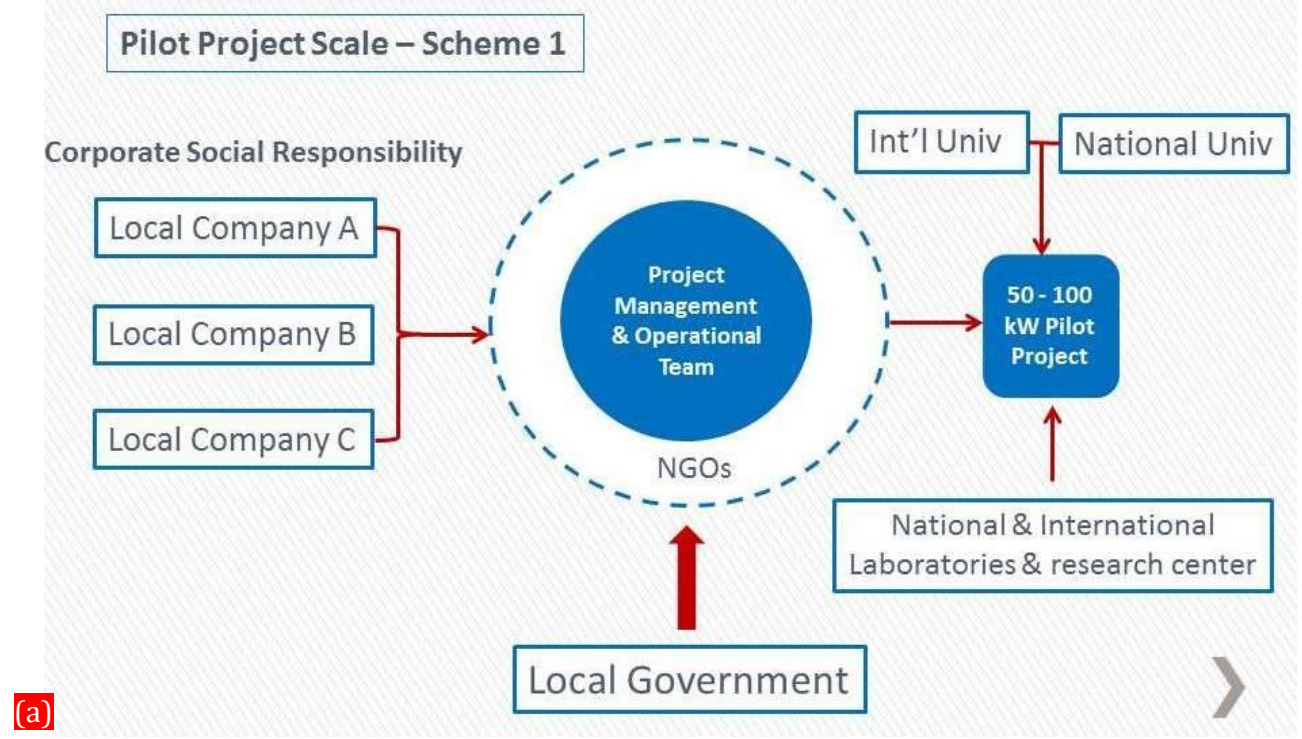

\section{Collaboration Scheme}

\section{Pilot Project Scale - Scheme 2}

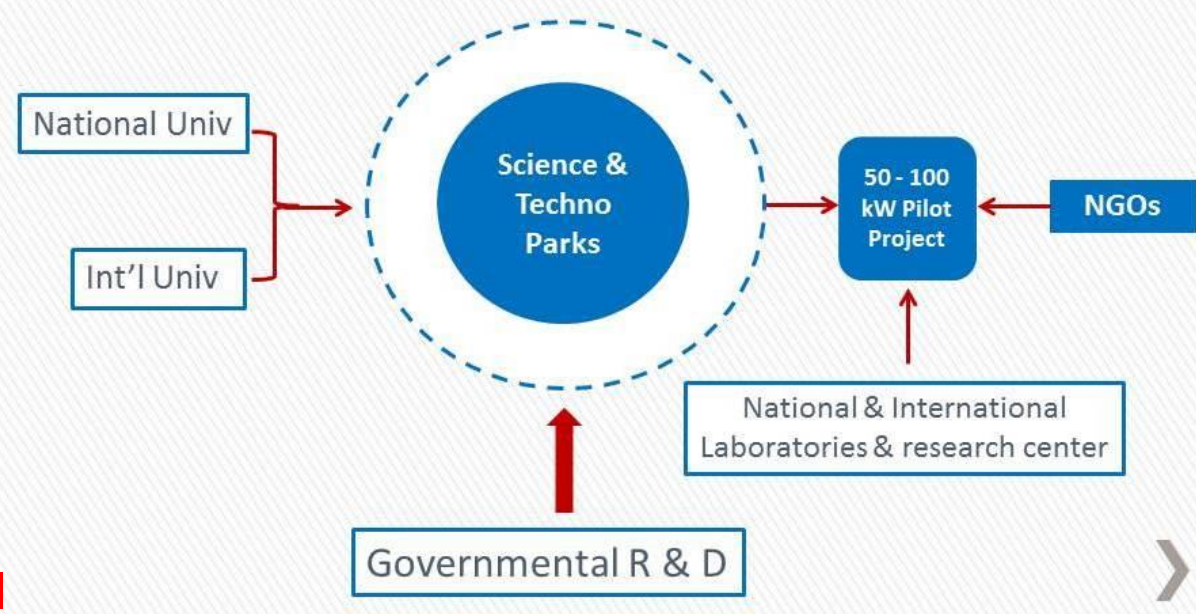




\section{Collaboration Scheme}

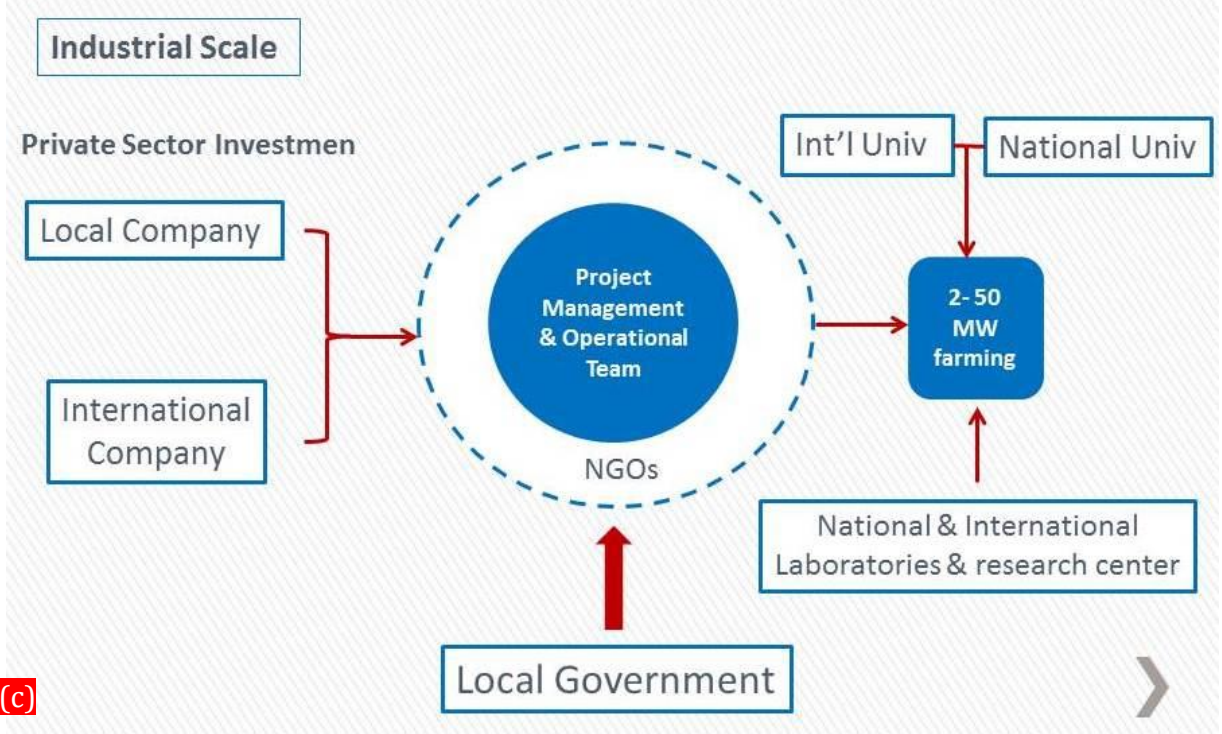

Gambar 3.

(a) Skema kolaborasi tipe 1 untuk skala percontohan penerapanenergi arus laut di Indonesia

(b) Skema kolaborasi tipe 2 untuk skala percontohan penerapanenergi arus laut di Indonesia

(c) Skema kolaborasi untuk skala industry penerapan energi arus laut di Indonesia

Index Term - Energi Laut, pemerataan akses energi (listrik), mengurangi penggunaan energi konvensional, pendekatan kolaboratif, strategi "double track". 